\title{
Filtration and clearance rates of Anadara grandis juveniles (Pelecypoda, Arcidae) with different temperatures and suspended matter concentrations
}

\author{
Anselmo Miranda-Baeza ${ }^{1,3 *}$, Domenico Voltolina ${ }^{2}$ \& Beatriz Cordero-Esquivel ${ }^{3}$ \\ 1 Centro de Estudios Superiores del Estado de Sonora, Unidad Académica Navojoa, P.O. Box 455, Navojoa, Sonora, \\ 85800, Mexico. Tel/Fax (+52 642) 4227576 \\ 2 Centro de Investigaciones Biológicas del Noroeste, P.O. Box 1132, Mazatlán, Sinaloa, 82000, Mexico \\ 3 Centro de Investigación Científica y de Educación Superior de Ensenada (CICESE), P.O. Box 2732, Ensenada, B.C. \\ 22860, Mexico \\ * Corresponding author: miranda@cicese.mx, amiranda@cesuesnavojoa.net
}

\author{
Received 01-XI-2004. C Corrected 06-X-2005. Accepted 15-III-2006.
}

\begin{abstract}
The mangrove cockle Anadara grandis (Broderip and Sowerby, 1829) is a potential candidate for aquaculture and for bioremediation of aquaculture effluents in the tropical and subtropical coastal areas of the eastern Pacific Ocean. Laboratory-produced spat are available, but there is no information on their responses to the range of environmental conditions to which they might be subject during the growth cycle. The aim of this study was to evaluate the filtration and clearance rates of $A$. grandis spat (shell length $9.50 \pm 0.37 \mathrm{~mm}$ ) with a food concentration $\left(7.5 \mathrm{mg} \cdot \mathrm{l}^{-1}\right)$ at four different temperatures $\left(22,25,28\right.$ and $31{ }^{\circ} \mathrm{C}$, with $\mathrm{pH}=7.5 \pm 0.2$ and $\mathrm{O}_{2}$ concentration of $6.4 \pm 0.5 \mathrm{mg} \cdot 1^{-1}$; experiment one); and with a temperature $\left(25^{\circ} \mathrm{C}\right)$ and five concentrations of suspended matter (from 7.5 to $29 \mathrm{mg} \cdot \mathrm{l}^{-1}$ and $\mathrm{pH}$ and $\mathrm{O}_{2}$ values of $7.9 \pm 0.2$ and $6.8 \pm 0.4 \mathrm{mg} \cdot \mathrm{l}^{-1}$; experiment two). Filtration and clearance rates were highest at $25^{\circ} \mathrm{C}$ and significantly different $(\mathrm{p}<.05)$ from those obtained at 22 , 28 and $31{ }^{\circ} \mathrm{C}$; the clearance rates had the same tendency but the differences were not significant $(\mathrm{p}>.05)$. In the second experiment filtration increased according to the amount of food available, but there were no significant differences ( $\mathrm{p}>.05$ ) between 7.5 and $11 \mathrm{mg} \cdot \mathrm{l}^{-1}$ and from 22.4 to $29 \mathrm{mg} \cdot \mathrm{l}^{-1}$. The trend was similar for clearance, and in this case significant differences were found $(\mathrm{p}<.05)$ between $7.5,22.4$ and $29 \mathrm{mg} \cdot \mathrm{l}^{-1}$. Filtration at $31^{\circ} \mathrm{C}$ was close to $80 \%$ at the optimum temperature of $25^{\circ} \mathrm{C}$, which indicates that $A$. grandis is a good candidate for tropical aquaculture. Clearance increased with high concentrations of suspended solids, but the production of biodeposits could be a source of environmental concern. Therefore, the possibility of using this species for bioremediation of aquaculture effluents should be studied with larger specimens and at higher seston concentrations. Rev. Biol. Trop. 54 (3): 787-792. Epub 2006 Sept. 29.
\end{abstract}

Key words: Anadara grandis, filtration rate, clearance rate, temperature, suspended matter.

The mangrove cockle Anadara grandis (Broderip and Sowerby, 1829) is a bivalve mollusc with maximum shell length of $10 \mathrm{~cm}$ and shell height of $7 \mathrm{~cm}$, that lives in the soft bottoms of the intertidal zone of the coastal lagoons of the eastern Pacific ocean, from Bahia Magdalena, Mexico, to Bahia de Tumbes, Peru (Mackenzie 2001).

In Mexico, this species shares habitat and common name (pata de mula: mule's hoof) with Anadara tuberculosa (Sowerby, 1833). Both are harvested for human consumption and are potential candidates for aquaculture. In addition, because of their local origin, they could be used for bioremediation of the effluents of the numerous shrimp farms of the coastal areas of the Mexican northwest, instead of other non native bivalves such as Crassostrea gigas and C. virginica, that have been found adequate for this purpose (Shpigel and Blaylock 1991, Jakob et al. 1993).

Information is available on the reproductive biology and fisheries of the mangrove cockles of the Pacific coasts of Latin America 
(Cruz 1982, 1984, 1987, Cruz and Palacios 1983, Borrero 1986, Mackenzie 2001) and on the filtration activity of $A$. tuberculosa under conditions of chemical stress (Wong et al. 1997), but there is no information on other biological characteristics of either species. In particular, their responses to the environmental factors that might affect the potential of this species for aquaculture and effluent bioremediation are still unknown.

Temperature and suspended matter concentration are among the most important variables that affect the filtration rate of molluscs (Winter 1978), and their response depends mainly on the species and on the range of variability of both factors in its natural habitat (Jørgensen 1990). The aim of this study was to obtain information on the filtration and clearance rates of $A$. grandis spat under different temperatures, and with different food concentrations.

\section{MATERIALS AND METHODS}

A. grandis spat were donated by the mollusc hatchery of the Centro de Investigaciones Biológicas del Noroeste and acclimated during two weeks to the experimental temperatures in artificial upwelling systems, using as food a mixture in equal parts of the microalgae Isochrysis sp. (Tahitian Isochrysis) and Pavlova lutheri. At the end of the acclimation period there were no differences in size and weight: mean shell length was $9.50 \pm 0.37 \mathrm{~mm}$; shell height was $7.11 \pm 0.16 \mathrm{~mm}$ and total dry weight (including shell) was $19.34 \pm 0.40 \mathrm{mg}$.

Filtration rates were measured in open $100 \mathrm{ml}$ acrylic chambers with a continuous flow $\left(400 \mathrm{ml} \cdot \mathrm{h}^{-1}\right)$ of $1-\mu \mathrm{m}$ filtered seawater, with $37 \pm 1 \%$ o salinity and the appropriate temperature and food ration, kept in suspension by profuse stirring with air bubbling. The experiments lasted $8 \mathrm{~h}$, with four replicate chambers with five organisms for each treatment.

In the first experiment, filtration rates were measured keeping constant the food concentration at $7.5 \mathrm{mg} \cdot \mathrm{l}^{-1}$. Oxygen was $6.4 \pm 0.5 \mathrm{mg} \cdot \mathrm{l}^{-1}$, $\mathrm{pH}$ was $7.5 \pm 0.2$ and the experimental tempera- tures $\left(22,25,28\right.$ and $\left.31^{\circ} \mathrm{C}\right)$ covered the annual range of the surface coastal waters of the Mexican tropical Pacific (Pacheco-Sandoval 1991) and of the southern part of the Gulf of California (Alvarez-Borrego 1983).

The second experiment was run at the temperature that gave the highest filtration. Oxygen and $\mathrm{pH}$ were $6.8 \pm 0.4 \mathrm{mg} \cdot \mathrm{l}^{-1}$ and $7.9 \pm 0.2$, and food concentrations were $7.5,11,15,22.4$ and $29 \mathrm{mg} \cdot \mathrm{l}^{-1}$, obtained by mixing in equal parts the microalgae Isochrysis sp. and bottom sediment collected from a local lagoon, washed, sterilized and strained through a $30 \mu \mathrm{m}$ sieve. After this treatment, the mean particle size of the sediment was $8.2 \pm 1.6 \mu \mathrm{m}$, which is similar to that of Isochrysis sp.

Before the beginning of this experiment, the organisms were acclimated during $24 \mathrm{~h}$ to each experimental ration. Food availability was measured as total dry weight (TDW) in triplicate $50 \mathrm{ml}$ samples taken simultaneously 2, 4 and $7 \mathrm{~h}$ after the beginning of the experiment from the inflow of each chamber, concentrated on precalibrated $25 \mathrm{~mm}$ Whatman GF-C glass fiber filter, rinsed with 3\% ammonium formate to eliminate sea salt, dried to constant weight in a convection oven at $65^{\circ} \mathrm{C}$, weighed to the nearest $0.01 \mathrm{mg}$ in a semimicro analytical balance and ashed later in a muffle furnace to obtain their inorganic content. The biodeposits (pseudofaeces and faeces) were collected after two, 4 and $8 \mathrm{~h}$, and treated as the seston samples. The filtration rates (FR, in $\mathrm{mg}$ of seston TDW $\cdot \mathrm{h}^{-1} \cdot$ ind $\left.^{-1}\right)$ were calculated using the equation suggested by Hawkins et al. (1998).

$$
\mathrm{FR}=\left[\left(\mathrm{PIM}_{\mathrm{b}} \cdot \mathrm{t}^{-1}\right) \cdot\left(\mathrm{TPM}_{\mathrm{s}} \cdot \mathrm{PIM}_{\mathrm{s}}^{-1}\right)\right] \cdot \mathrm{n}^{-1}
$$

Where $\mathrm{PIM}_{\mathrm{b}}$ is the particulate inorganic matter (mg) in the biodeposits, $t$ is the time between measurements (h), TPM $\mathrm{s}$ and $\mathrm{PIM}_{\mathrm{s}}$ are the total and inorganic suspended solids (mg) and $\mathrm{n}$ is the number of specimens in the chamber. The clearance rate $\left(\mathrm{CR}\right.$, in $1 \cdot \mathrm{h}^{-1} \cdot$ ind $\left.^{-1}\right)$ was calculated as in Lefebvre et al. (2000):

$$
\mathrm{CR}=\left[\left(\mathrm{PIM}_{\mathrm{b}} \cdot \mathrm{t}^{-1}\right) \cdot \mathrm{PIM}_{\mathrm{s}}^{-1}\right] \cdot \mathrm{n}^{-1}
$$


Each experiment gave three blocks of samples for each treatment, obtained at the three sampling times, and the data were normal and homoscedastic. Therefore, the results were compared by one-way block analysis of variance tests with $\alpha=0.05$, separating the differences with Tukey's HSD tests (Zar 1996).

\section{RESULTS}

In either experiment, there were no differences within treatments due to the time of sampling ( $\mathrm{p}>.05)$ but temperature and the amount of food supplied were sources of significant differences $(F=16.82 ; p<.0001$ in the first case and $F=21.74 ; p<.0001$ in the second).

The response of filtration in temperature was not linear, because it increased significantly between 22 and $25^{\circ} \mathrm{C}$, but it decreased at $28^{\circ} \mathrm{C}$ and remained approximately stable at $31^{\circ} \mathrm{C}$. This response is adequately described by the quadratic equation: $\mathrm{FR}=-1.685+0.149 \mathrm{t}-0.0028 \mathrm{t}^{2}$ $\left(\mathrm{R}^{2}=0.77\right)$ where $\mathrm{t}$ is water temperature. Clearance rates showed a similar tendency, but the differences were not significant (Table 1).
The second experiment showed that filtration increased continuously with increasing amounts of food available, but the difference was not significant between 7.5 and $11 \mathrm{mg} \cdot \mathrm{l}^{-1}$, it increased significantly with 15 , and again with $22.4 \mathrm{mg} \cdot \mathrm{l}^{-1}$. The further increase at 29 $\mathrm{mg} \cdot \mathrm{l}^{-1}$ was not significant in comparison with the previous ration. Clearance was similar from 7.5 to $15 \mathrm{mg} \cdot \mathrm{l}^{-1}$, it increased significantly at $22.4 \mathrm{mg} \cdot \mathrm{l}^{-1}$, but only in comparison to the lowest food concentration, and the highest value was with $29 \mathrm{mg} \cdot \mathrm{l}^{-1}$ (Table 2).

The responses to different concentrations of suspended solids was not linear (Fig. 1), and in this case the best fit for filtration was with the equation $\mathrm{FR}=-0.067+0.1497 \mathrm{Ln}$ TPM $\left(\mathrm{R}^{2}=0.986\right)$, and that for clearance was $\mathrm{CR}=$ $0.0151 \mathrm{e}^{(0.017 \mathrm{TPM})}\left(\mathrm{R}^{2}=0.914\right)$.

\section{DISCUSSION}

The lack of difference of filtration and clearance rates at different sampling times may be taken as proof that, after two hours in the chamber, the organisms had recovered from the

TABLE 1

Mean values \pm standard deviation of filtration and clearance rates of Anadara grandis at 22, 25, 28 and $31{ }^{\circ} \mathrm{C}$

\begin{tabular}{ccccc} 
& \multicolumn{3}{c}{ Temperature $\left({ }^{\circ} \mathrm{C}\right)$} & 28 \\
$\mathrm{FR}\left(\mathrm{mg} \cdot \mathrm{h}^{-1} \cdot \mathrm{ind}^{-1}\right)$ & $0.240 \pm 0.038^{\mathrm{a}}$ & $0.318 \pm 0.023^{\mathrm{c}}$ & $0.283 \pm 0.033^{\mathrm{b}}$ & $0.260 \pm 0.025^{\mathrm{ab}}$ \\
$\mathrm{CR}\left(1 \cdot \mathrm{h}^{-1} \cdot \mathrm{ind}^{-1}\right)$ & $0.018 \pm 0.003^{\mathrm{a}}$ & $0.022 \pm 0.004^{\mathrm{a}}$ & $0.018 \pm 0.004^{\mathrm{a}}$ & $0.019 \pm 0.006^{\mathrm{a}}$
\end{tabular}

Equal or common letters indicate lack of significant differences (one-way ANOVA and Tukey's tests, $\alpha=0.05$ ) $\mathrm{a} \leq \mathrm{ab} \leq \mathrm{b}$ $<\mathrm{c}$ and $\mathrm{a}<\mathrm{b}<\mathrm{c}$.

TABLE 2

Mean values \pm standard deviation of filtration and clearance rates (FR and CR), with five concentrations of total particulate matter (TPM)

\begin{tabular}{cccccc}
\multicolumn{5}{c}{ TPM $\left(\mathrm{mg} \cdot 1^{-1}\right)$} \\
& 7.5 & 11 & 15 & 22.4 & 29 \\
FR $\left(\mathrm{mg} \cdot \mathrm{h}^{-1} \cdot \mathrm{ind}^{-1}\right)$ & $0.24 \pm 0.037^{\mathrm{a}}$ & $0.28 \pm 0.021^{\mathrm{a}}$ & $0.34 \pm .028^{\mathrm{b}}$ & $0.41 \pm 0.042^{\mathrm{c}}$ & $0.43 \pm 0.044^{\mathrm{c}}$ \\
$\mathrm{CR}\left(\mathrm{l} \cdot \mathrm{h}^{-1} \cdot \mathrm{ind}^{-1}\right)$ & $0.018 \pm 0.002^{\mathrm{a}}$ & $0.018 \pm 0.002^{\mathrm{ab}}$ & $0.019 \pm 0.002^{\mathrm{ab}}$ & $0.021 \pm 0.003^{\mathrm{b}}$ & $0.026 \pm 0.003^{\mathrm{c}}$
\end{tabular}

Different letters indicate significant differences (one-way ANOVA and Tukey tests, $\alpha=0.05$ ) $\mathrm{a} \leq \mathrm{ab} \leq \mathrm{b}<\mathrm{c}$ and $\mathrm{a}<\mathrm{b}<\mathrm{c}$. 


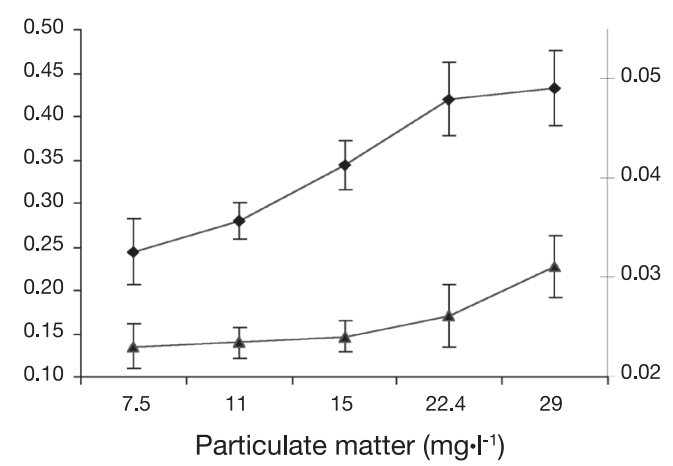

Fig. 1. Filtration rate (Full diamonds, left han scale, in $\mathrm{mg}$ / $\mathrm{h} /$ ind) and clearance rate (full triangles, right hand scale, in 1/h/ind) of Anadara grandis with diferent concentrations of suspended matter.

initial stress due to handling during selection of the specimens used for the experiments.

There is no previous information on the thermal tolerance of $A$. grandis, but its geographic distribution is similar to that of $A$. tuberculosa, that has been found in waters with temperatures of up to $35^{\circ} \mathrm{C}$ (Baqueiro 1980), and extensive $A$. grandis populations live in Agiabampo Lagoon, in the southern part of the Mexican state of Sonora, where surface temperatures range between $19^{\circ} \mathrm{C}$ in winter and $32{ }^{\circ} \mathrm{C}$ in summer (Miranda-Baeza and LunaGuzmán 1997).

Although our results show that filtration rates are affected significantly by temperature, the decline at the high end of the experimental thermal range is far less important than that described for Mytilus edulis by Schulte (1975), who found a sudden and important drop of both rates between 28 and $30{ }^{\circ} \mathrm{C}$. In this case, they declined to only $88-81 \%$ of those calculated at the optimum temperature of $25^{\circ} \mathrm{C}$, that suggests that this species may be considered adequate for aquaculture in the lagoons and embayments of the Mexican Pacific coast.

The amount of suspended matter retained in $1 \mathrm{~h}$ by one organism varied within a narrow range, between 1.24 and $1.60 \%$ of the total body dry weight. The lack of significant differences between samples obtained at different times indicates that filtration is continuous. Therefore, between 0.29 and $0.34 \mathrm{~g}$ of particulates may be retained in one day by $1 \mathrm{~g}$ of spat (shell included) of $A$. grandis of the same size than our experimental organisms when the particulate matter is equivalent to 7.5 $\mathrm{mg} \cdot \mathrm{l}^{-1}$, that would increase up to a maximum of $0.53 \mathrm{~g}$ with a temperature of $25^{\circ} \mathrm{C}$ and 29 $\mathrm{mg} \cdot \mathrm{l}^{-1}$ of suspended solids.

These values seem to indicate that, because of their high filtration efficiency, A. grandis spat could be grown even at seston concentrations higher than those found in natural water bodies of high productivity (Marmolejo and Páez-Osuna 1990, Alonso-Rodríguez 1998). However, the effluents of semi-intensive shrimp farms may reach concentrations in excess of 40 $\mathrm{mg} \cdot \mathrm{l}^{-1}$ (Páez-Osuna and Ruiz-Fernández 2001), that might cause a decline in clearance if the concentrations exceeded the maximum critical threshold (Winter 1978). In addition, although the production of pseudofaeces was not quantified regularly, it was noticed occasionally starting at $15 \mathrm{mg} \cdot \mathrm{l}^{-1}$ and pseudofaeces represented close to $60 \%$ of the particles retained at 29 $\mathrm{mg} \cdot 1^{-1}$. This could be a source of environmental concern, because of the high amount of untreated (undigested) biodeposits.

The results of this study suggest that A. grandis is a good candidate for tropical aquaculture, but the possibility of its use for bioremediation of penaeid intensive or semiintensive farm effluents should be confirmed with additional studies with larger specimens, and increasing the concentration of particulate matter to the levels likely to be found in this type of effluents.

\section{ACKNOWLEDGMENTS}

M. Robles donated the A. grandis spat; F. Valenzuela helped in the design of the experimental unit and L. Trujillo supplied the microalgae strains. This research is part of the experimental work of the first author, in partial fulfillment of the requisites towards his Ph.D. degree at CICESE, with a scholarship granted by the SEP-PROMEP program. 


\section{RESUMEN}

La almeja Anadara grandis (Broderip and Sowerby, 1829) es un candidato potencial para la acuicultura y la biorremediación de efluentes acuícolas en las áreas costeras tropicales y subtropicales del océano Pacífico oriental. Se dispone de semilla producida en laboratorio, sin embargo no hay información sobre sus respuestas a los intervalos de las condiciones ambientales a las cuales puede estar sujeta durante el periodo de crecimiento. El objetivo de este estudio fue evaluar las tasas de filtración y de clarificación de semilla de A. grandis (largo de la concha $=9.50 \pm 0.37 \mathrm{~mm}$ ) con una concentración de alimento $\left(7.5 \mathrm{mg} \cdot \mathrm{l}^{-1}\right)$ y cuatro diferentes temperaturas $(22,25,28 \mathrm{y}$ $31{ }^{\circ} \mathrm{C}$ con $\mathrm{pH}=7.5 \pm 0.2$, concentración de $\mathrm{O}_{2}$ de $6.4 \pm 0.5$ $\mathrm{mg} \cdot \mathrm{l}^{-1}$; experimento uno); y con una temperatura $\left(25^{\circ} \mathrm{C}\right)$ y cinco concentraciones de material suspendido (de 7.5 a $29 \mathrm{mg} \cdot \mathrm{l}^{-1}$ y niveles de $\mathrm{pH}$ y $\mathrm{O}_{2}$ de $7.9 \pm 0.2$ y $6.8 \pm 0.4 \mathrm{mg} \cdot \mathrm{l}^{-1}$, experimento dos). Las tasas de filtración y de clarificación fueron máximas a $25^{\circ} \mathrm{C}$ y significativamente diferentes $(\mathrm{p}<.05)$ de las obtenidas a 22,28 y $31^{\circ} \mathrm{C}$; la tasa de clarificación presentó la misma tendencia, pero las diferencias no fueron significativas $(\mathrm{p}>.05)$. En el segundo experimento, se registró un incremento de la filtración, de acuerdo a la concentración de alimento, pero sin diferencias significativas ( $\mathrm{p}>.05$ ) en los intervalos 7.5 a $11 \mathrm{mg} \cdot \mathrm{l}^{-1}$ y 22.4 a 29 $\mathrm{mg} \cdot \mathrm{l}^{-1}$. La clarificación mostró la misma tendencia y en este caso se encontraron diferencias significativas $(\mathrm{p}<.05)$ entre 7.5, 22.4 y $29 \mathrm{mg} \cdot \mathrm{l}^{-1}$. La cantidad de sólidos ingeridos a $31{ }^{\circ} \mathrm{C}$ representó más del $80 \%$ de la filtración a $25^{\circ} \mathrm{C}$, que indica que $A$. grandis es un buen candidato para la acuicultura tropical. Con altas concentraciones de sólidos la clarificación aumentó, pero se notó una producción de pseudoheces que pudieran ser fuente de problemas ambientales, por lo cual se sugiere que la posibilidad de utilizar esta especie para la biorremediación de efluentes debería ser investigada con especímenes de mayores dimensiones y con concentraciones de seston más altas.

Palabras clave: Anadara grandis, tasas de filtración, tasa de clarificación, temperatura, sólidos suspendidos.

\section{REFERENCES}

Alonso-Rodríguez, R. 1998. Ocurrencia de mareas rojas y calidad del agua en la zona sur de la Bahía de Mazatlán. Tesis de maestría, Universidad Nacional Autónoma de México, Mexico D.F., Mexico. 174 p.

Alvarez-Borrego, S. 1983. Gulf of California, p. 427-449. In B.H. Ketchum (ed.). Estuaries and enclosed seas. Elsevier, Amsterdam, Holland.

Baqueiro, E. 1980. Population structure of the mangrove cockle Anadara tuberculosa (Sowerby, 1833) from eight mangrove swamps in Magdalena and Almejas Bays, Baja California Sur, Mexico. Proc. Nat. Shellfish Assoc. 70: 201-206.

Borrero, J.F. 1986. The collection of early juveniles of Anadara spp. as a potential source of seed for culturing mangrove cockles on the Pacific coast of Colombia. Aquaculture 59: 61-69.

Cruz, R.A. 1982. Variación mensual del índice de condición del molusco Anadara tuberculosa (Pelecypoda: Arcidae) en Punta Morales, Puntarenas, Costa Rica. Rev. Biol. Trop. 30: 1-4.

Cruz, R.A. 1984. Algunos aspectos de la reproducción en Anadara tuberculosa (Pelecypoda:Arcidae) de Punta Morales, Punta Arenas, Costa Rica. Rev. Biol. Trop. 32: $45-50$.

Cruz, R.A. 1987. Tamaño y madurez sexual en Anadara grandis (Pelecypoda:Arcidae). Brenesia 27: 9-12.

Cruz, R.A. \& J.A. Palacios. 1983. Biometría del molusco Anadara tuberculosa (Pelecypoda:Arcidae) en Punta Morales, Puntarenas, Costa Rica. Rev. Biol. Trop. 30: 175-179.

Hawkins, A.J., B.L. Bayne, S. Bougrier, M. Héral, J.I.P. Iglesias, E. Navarro, R.F.M Smith \& M.B. Urrutia. 1998. Some general relationships in comparing the feeding physiology of suspension-feeding bivalve mollusks. J. Exp. Mar. Biol. Ecol. 219: 87-103.

Jakob, S.G., D. Pruder \& W. Jaw-Kai. 1993. Growth trial with the American oyster Crassostrea virginica using shrimp pond water as feed. J. World Aquac. Soc. 3: 344-351.

Jørgensen, B.C. 1990. Bivalve filter feeding: hydrodynamics, bioenergetics, physiology and ecology. Olsen and Olsen, Fredensborg, Denmark. 141 p.

Lefebvre, S., L. Barrillé \& M. Clerck. 2000. Pacific oyster (Crassostrea gigas) feeding responses to a fish-farm effluent. Aquaculture 187: 185-198.

Mackenzie, C.L. Jr. 2001. The fisheries for mangrove cockles, Anadara spp., from Mexico to Peru, with descriptions of their habitats and biology, the fishermen's lives and the effects of shrimp farming. Mar. Fish. Rev. 63: 1-39.

Marmolejo, R.C. \& F. Páez-Osuna. 1990. Trace metals in coastal lagoon bivalves Mytella striata. Bull. Env. Contam. Toxicol. 45: 545-551.

Miranda-Baeza, A. \& C. Luna-Guzmán. 1997. Cultivo piloto de almeja catarina Argopecten circularis en la bahía de Agiabampo, Sonora. Oceanología 2: 67-78. 
Pacheco-Sandoval, P. 1991. Pacífico tropical mexicano. Cabo Corrientes a la frontera con Guatemala, p. 151-176. In G. De la Lanza-Espino (ed.). Oceanografía de mares mexicanos. AGT, Mexico D.F., Mexico.

Páez-Osuna, F. \& A.C. Ruiz-Fernández. 2001. La calidad del agua en la camaronicultura: conceptos, manejo y normatividad, p. 100-134. In F. PáezOsuna (ed.). Camaronicultura y medio ambiente. Universidad Nacional Autónoma de México, Instituto de Ciencias del Mar y Limnología, Mexico D.F., Mexico.

Schulte, E.H. 1975. Influence of algal concentration and temperature on the filtration rate of Mytilus edulis. Mar. Biol. 30: 331-341.
Shpigel, M. \& R.A. Blaylock. 1991. The Pacific oyster, Crassostrea gigas, as a biological filter for a marine fish aquaculture pond. Aquaculture 92: 187-197.

Winter, J.E. 1978. A review on the knowledge of suspension-feeding in lamellibranchiate bivalves, with special reference to artificial aquaculture systems. Aquaculture 13: 1-13.

Wong, E., M.I. Gonzáles, F. Antillón \& E. Glenn. 1997. Efecto de varios agentes, a diferentes niveles de $\mathrm{pH}$, sobre la tasa de filtración de la piangua, Anadara tuberculosa (Prionodontida: Arcidae). Rev. Biol. Trop. 45: 1-8.

Zar, J. 1996. Biostatistical Analysis. Prentice Hall, Upper Saddle River, New Jersey, USA. 720 p. 